\title{
Halkla İlişkiler Perspektifinden Kurumsal Sosyal Sorumluluk Projeleri: Meslek Yüksekokulu Öğrencileri Üzerine Bir Araştırma
}

\author{
Corporate Social Responsibility Projects from a Public Relations Perspective: A \\ Research on Vocational School Students
}

\author{
Emel DEMIR ASKEROĞLU*
}

$\ddot{O} Z$

Yoğun rekabet ortamında şirketler sosyal bir amacı destekleme ihtiyacı duymaktadır. Böylelikle hedef kitlesi ile arasında bir ilişki kurma imkânı bulmaktadır. Günümüzde bireylerin toplumsal sorunlara duyarlı olması, ürün ve hizmet tercihlerinde farkl kriterleri de göz önünde bulundurmasına sebep olmaktadır. Bu çalışmada halkla ilişkiler perspektifinden kurumsal sosyal sorumluluk projelerinin inandırıcı̆̆ına yönelik algıyı ortaya çıkarmak amaçlanmaktadır. Bir meslek yüksekokulu ögrencileri üzerinde nicel araştırma yöntemlerinden yüz yüze anket çalışması gerçekleştirilmiştir. Basit rastlantısal örneklem yöntemi ile seçilen 250 kişi ile gerçekleştirilen çalışmanın örneklemi, bir MYO'nun 5 farklı programında ĕgitim gören birinci ve ikinci sını ögrrencileri arasından seçilmiştir. Araştırma sonucu elde edilen verilerin analizi SPSS 22 programı ile yapılmış ve \%95 güven düzeyi ile çalışılmıştır. İşletmelerin faaliyet gösterdikleri toplumların ihtiyaçlarına uygun olarak gerçekleştirilen çevre, sağlık, eğitim, kültür-sanat alanlarında gerçekleştirilen kurumsal sosyal sorumluluk projelerinin meslek yüksekokulu ögrencileri tarafindan hangi koşullarda inandırıcı algllandı ğ ve toplumun hangi alanlarda projelere ihtiyaç duyduğu ortaya konulmaya çalışılmıştır. Araştırma sonuçlarına göre öğrenciler öncelikli olarak toplumun sorunlarına yönelik eksikliklerin giderilmesi gerektiğini verdikleri yanıtlar ile dile getirmektedir. Özellikle eğitim, sağlık, çevre gibi temel sorunların çözümü için projelere öncelik istemektedirler. Daha sonraki aşamada kültür-sanat faaliyetleri yer almaktadır. Bu nedenle ülkelerin sorunlarına duyarlılık gösteren projeler gerçekleştirmek önemli hale gelmektedir.

ANAHTAR KELIMELER

Halkla İlişkiler, Kurumsal Sosyal Sorumluluk, Kurumsal Sosyal Sorumluluk Projeleri

\begin{abstract}
In a highly competitive environment, companies need to support a social goal. Thus, it finds the opportunity to establish a relationship with its target audience. The fact that individuals are sensitive to social problems causes them to consider different criteria in product and service preferences. In this study, it is aimed to reveal the perception towards the credibility of corporate social responsibility projects from the public relations perspective. A face-to-face survey was conducted on the students of a vocational school. The sample of the study, which was conducted with 250 randomly selected individuals, was selected among the first and second grade students studying in 5 different programs of a Vocational School. The data obtained from the research were analyzed with SPSS 22 program and 95\% confidence level was used. It has been tried to put forward the conditions under which the students of vocational high schools perceive the corporate social responsibility projects realized in the fields of environment, health, education, culture and arts, which are realized in accordance with the needs of the societies in which businesses operate, and in which areas the society needs projects. According to the results of the research, the students first of all stated that they should overcome the deficiencies regarding the problems of the society with their answers. They want to prioritize projects in order to solve basic problems such as education, health and environment. In the next stage, culture and art activities take place. Therefore, it becomes important to realize projects that are sensitive to the problems of countries.
\end{abstract}

KEYWORDS

Public Relations, Corporate Social Responsibilty, Corporate Social Responsibility Projects

\begin{tabular}{|c|c|c|}
\hline \multicolumn{2}{|r|}{$\begin{array}{c}\text { Makale Gelis Tarihi / Submission Date } \\
\text { 08.05.2019 }\end{array}$} & $\begin{array}{c}\text { Makale Kabul Tarihi / Date of Acceptance } \\
\text { 21.06.2019 }\end{array}$ \\
\hline Atıf & $\begin{array}{l}\text { Askeroğlu, E. D. (2019). Halkla İlişkile } \\
\text { Öğrencileri Üzerine Bir Araştırma. Sel }\end{array}$ & $\begin{array}{l}\text { asal Sosyal Sorumluluk Projeleri: Meslek Yüksekokulu } \\
\text { Bilimler Meslek Yüksekokulu Dergisi, } 22 \text { (2), 508-525. }\end{array}$ \\
\hline
\end{tabular}

* Öğr.Gör.Dr., Tekirdağ Namık Kemal Üniversitesi, Çerkezköy Meslek Yüksekokulu, Pazarlama ve Reklamcıllk Bölümü, edemir@nku.edu.tr, OCRID: 0000-0003-3953-5734 


\section{GİRIŞ}

İşletmelerin amaçları doğrultusunda, işletme ile hedef kitlesi arasında ortak bir zemin oluşturabilmesi ve çıkarların dengelenmesini sağlaması gerekmektedir. İşletmeler çıkarlarının ötesinde faaliyet gösterdikleri toplumların varlıklarını kabul ederek, onların sorunlarına yönelerek adımlar atması sorumlu davranışın göstergesi olmaktadır. Bu doğrultuda atılan adımlar olumlu imaj olarak işletmelere yansımaktadır. Halkla ilişkiler perspektifinden bakıldığında işletmeni $n$ imajını yükseltmek öncelikli amaçlardan olduğundan kurumsal sosyal sorumululuk yaklaşımı sergilemek de halkla ilişkiler çerçevesinde önem oluşturmaktadır (Peltekoğlu, 2012:189). İşletmelerin hedef kitlelerine ulaşabilmek için izledikleri bir yol olarak kurumsal sosyal sorumluluk projeleri, toplum yararına faaliyetlerde bulunarak, toplum için faydalı adımlar atarak sorumluluk bilincini göstermekte ve olumlu imaj oluşturmak için ortam hazırlayabilmektedir.

Geçmişten günümüze birçok tanımı yapılan sosyal sorumluluk kavramı, işletmelerin faaliyet alanlarına göre yerine getirmekle yükümlü oldukları sorumluluklarının ötesinde toplumsal sorunları da göz önünde bulundurarak yapılan bir projeye destek vermek ya da kendi projelerini tasarlayarak sorunlara çözüm aramaya çalışmaktır. Hızla gelişen teknoloji ve artan rekabet koşulları ile birlikte işletmeler farklılaşabilmek ve rekabet avantajını elinde bulundurabilmek için kurumsal sosyal sorumluluk yaklaşımı ile hareket etmek durumundadirlar.

Toplumun işletmeden beklediği etik, yasal, ticari ve toplumsal beklentilerini karşılayan bir şekilde faaliyetini gerçekleştirmek olarak ifade edilen (Kotler ve Nancy, 2006:3) sosyal sorumluluk kavramı, gönüllü kurumsal uygulamalarla iç kaynaklardan da katkı sağlanarak toplumun refahını arttırma çabası göstermek olarak ifade edilmektedir (Kotler vd.,2012:14). Toplumun beklenti ve refahı esasına dayalı bir kurumsal sosyal sorumluluk anlayışı ile hareket eden işletmeler, eğitim, sağlık, çevre, kültürel yapı gibi alanlarda sosyal sorumluluk projeleri gerçekleştirilmesini sağlayarak, yalnızca kar odaklı olmadıklarını aynı zamanda sorumluluk bilincinde faaliyette bulunduklarını da gösterme olanağı bulmaktadırlar. Tüm bu alanlarda gerçekleştirilen projelerin hangilerinin daha öncelikli olması gerektiği konusu ise toplumun önceliklerine göre belirlenmesi gerekmektedir.

$\mathrm{Bu}$ çalışmada meslek yüksekokulu öğrencilerinin kurumsal sosyal sorumluluk projeleri türlerinden hangilerinin toplumda daha fazla gereksinim duyulduğunu ve bu projelerin ne kadar inandırıcı bulunduğunu ortaya koymak amaçlanmakla birlikte, halkla ilişkiler çerçevesinde bu projelerin işletmelere nasıl bir katkısı olabileceği üzerinde durulmaktadır. Kavramsal ve tarihsel süreciyle ele alınan kurumsal sosyal sorumluluk kavramı, uygulama alanları ve işletmelere katkıları ele alınarak araştırma gerçekleştirilmiştir.

\section{KURUMSAL SOSYAL SORUMLULUK KAVRAMI VE GELİ̧̧iMI}

Kurumsal sosyal sorumluluk kavramının (KSS), uzun bir tarihsel serüvene sahip olduğunu söylemek mümkündür. Yüzyıllardır iş dünyası tarafından toplum için endişeler duymasına rağmen, sosyal sorumluluk üzerine gerçekleştirilen literatür çalışmaları son elli yıldır özellikle Amerika Birleşik Devletler'de gerçekleştirilmektedir (Carroll, 1999: 268). Kurumsal sosyal sorumluluk kavramını açıklayabilmek için son elli yılda KSS kavramına yönelik bakış açılarını değerlendirmek gerekmektedir.

1950’li yıllarda KSS kavramına bakış iki ayrı açıdan ele alınmaktadır. Bu görüşlerden biri New Jersey'deki Standart Petrol Şirketi'ndeki eski bir yönetici olan Frank Abrams, yönetimin profesyonelleşmesiyle birlikte, şirketlerin sadece kârlar hakkında değil, aynı zamanda çalışanlar, müşteriler ve kamuoyunu da düşünmek zorunda olduklarını ileri sürmektedir. Aynı yıllarda, William C. Frederick, KSS literatürüne önemli bir katkı sağlayarak üç temel fikir geliştirmiştir. Bunlar, yöneticinin sorumluluğu, rekabetin dengeli hale getirilmesi, hayırseverlik ve iyi niyete dayalı iş destekleridir. Diğer taraftan, Levitt (1958), iş dünyası için KSS projelerini tehlikeli olarak nitelendirerek iş dünyasına uyarılarda bulunmaktadır. Levitt, sosyal kaygıların ve genel refahın iş dünyasının değil, devletin sorumluluğunda olması gerektiğini düşünmekte ve iş dünyasının kar güdüsünden uzaklaşmaması gerektiğini savunmaktadır (Carroll, Shabana, 2010: 86-87).

Davis (1960: 271) sosyal sorumluluğun belirsiz bir yaklaşım olduğunu, ancak yönetimsel bağlamda görülmesi gerektiğini savunmaktadır. Ayrıca sosyal açıdan sorumlu bazı iş kararlarının, uzun ve karmaşık bir mantık yürütme süreci ile şirkete uzun vadeli ekonomik kazanç getirme şansına sahip olduğu ve bu nedenle de sosyal açıdan sorumlu bakış açısını ileriye yönelik bir yatırım olabileceğini savunmuştur. Bu görüş, 1970'lerin sonlarında ve 1980 'lerde yaygın olarak kabul edildiği için oldukça ilgi çekicidir. Davis, sosyal sorumluluk ve iş gücü arasındaki ilişki üzerine odaklanır ve "iş adamlarının sosyal sorumluluklarının toplumsal güçleriyle orantılı olması gerektiğini” savunmaktadır (Carroll, 1999: 271).

Joseph W. McGuire İş ve Toplum (1963) adlı kitabında, "Sosyal sorumluluk düşüncesinin, kurumun sadece ekonomik ve yasal yükümlülükleri değil, bunun ötesinde topluma karşı sorumlulukları" olduğunu ifade ederek sosyal sorumluluğun tanımlanmasına katkıda bulunmaktadır (akt. Carroll, 1999). Bu tanımla sosyal 
sorumluluk anlayışının kurumun toplumsal yapısına yönelik yükümlülüklere yer vermesi, sosyal sorumluluk anlayışının işin ekonomik ve yasal boyutundan ötesi olduğu vurgusu görülmektedir.

1970'ler Morrell Heald tarafindan yazılan "İşin Sosyal Sorumlulukları: Şirket ve Toplum” adlı çalışmada sosyal sorumluluk tanımında kurumsal hayırseverlik ve toplum ilişkileri öne çıkarılmaktadır (Carroll, 1999: 273).

1980’lerde kurumsal sosyal sorumluluk, bir yükümlülük olarak görülüp, sendika ve hukuki düzeyde ele alınması gereken bir kavram olarak görülmeye başlanmıştır. Bu bakış açısında kurumsal sosyal sorumluluk gönüllülük dışında bir zorlayıcı faktöre bağlanmaktadır (Carroll, 1999: 284). Böylece 1980'li y1llardan sonra gönüllük ötesinde bir yükümlülük olarak ele alınmaya başlayan kurumsal sosyal sorumluluk, iş dünyası için her geçen gün daha da önemli hale gelmektedir.

90'lı yıllarda Carroll KSS ile ilgili yaklaşımına yeni bir boyut getirerek "kurumsal vatandaşlık" kavramını hayırseverlik kavramı yerine kullanılmıştır. Ayrıca KSS için gerekli olan mevcut durumun gözden geçirilmesi üzerinde durmuştur. Carroll, KSS'nin kabul görmesi için tüm iş sorumluluklarının yerine getirilmesine vurgu yapmaktadır. Carroll, dört çeşit sosyal sorumluluğun KSS'yi oluşturduğu ileri sürmektedir: ekonomik, yasal, etik ve hayırseverlik. Ayrıca, bu dört kategori veya KSS'nin bileşenleri olarak kabul edip bir piramit ile tasvir eder (Carroll, 1999: 289).

\section{Grafik1: Kurumsal Sosyal Sorumluluk Piramidi}

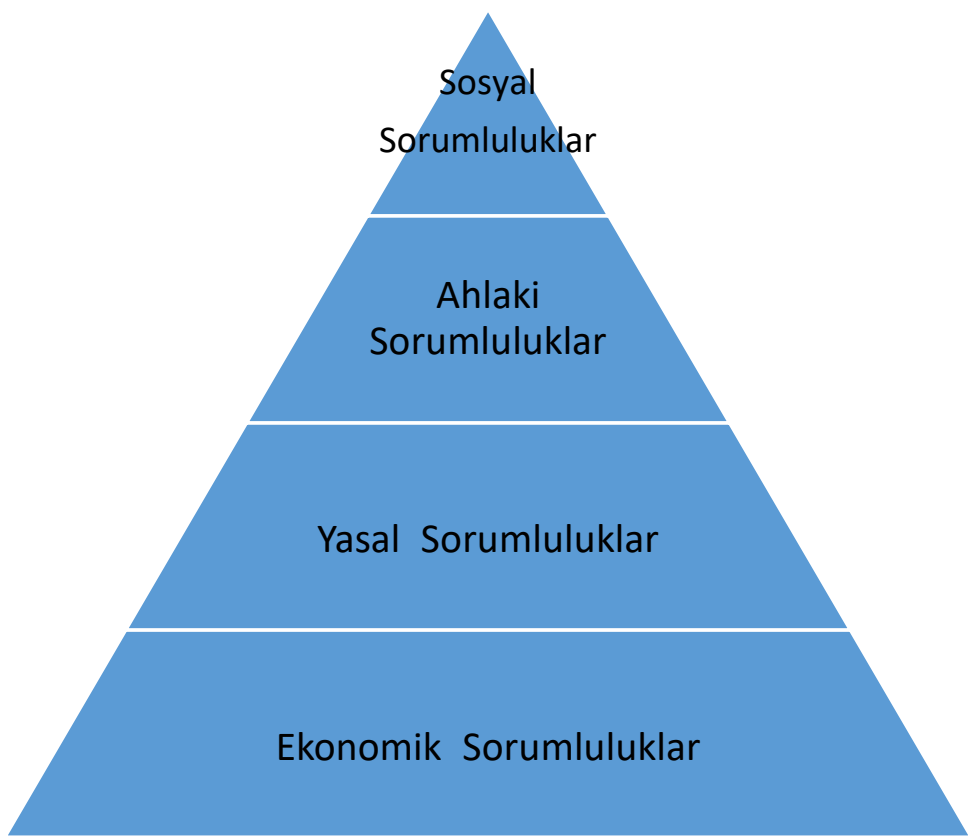

Kaynak: Peltekoğlu, 2012: 191.

KSS piramidi, ekonomik sorumlulukları taban olarak almaktadır. Bu tabanda olan ekonomik sorumluluklar temel işleve sahip olup, bu temelin üzerine yasal, ahlaki ve hayırseverlik çerçevesinde sosyal sorumluluk kategorileri inşa edilmektedir (Carroll, 1991: 42). Bu Piramitte yer alan her bir kategori sırasıyla işlemese dahi, her zaman yerine getirilmesi gereken katergorilerden oluşmaktadır. Carroll bir işletmelerin kar etmek, yasalara uymak, etik olmak ve iyi bir kurumsal vatandaş olmak için çaba sarf etmesi gerektiği üzerinde durmaktadır. İşletmelerin içinde bulundukları topluma karşı sorumluluklarına karş11ık gelen kurumsal vatandaşl1k kavramı, işletmelerin yükümlülüklerine yapılan bir vurgu olduğunu söylemek mümkündür. Özetle, kurumsal sosyal sorumluluk iş dünyasında, ekonomik, yasal ve gönüllü bir takım faaliyetleri kapsamaktadır.

Sosyal sorumluluğa farklı açılardan bakan birçok yaklaşım da mevcuttur. Sosyal sorumluluk kavramını, Friedman, sadece kar etmek, Davis, kar etmenin ötesine geçmek, McGuire; ekonomik ve yasal ihtiyaçların ötesine geçmek, Manne, gönüllü faaliyetler, Steiner, ekonomik, yasal, gönüllü faaliyetler olarak ifade etmektedir (Carroll, 1979: 499).

Ekonomik Sorumluluklar: İ̧̧letmeler varlıklarını sürdürebilmek için üretmek, ürettiklerini satmak ve kar etmekle yükümlüdürler. Toplumun istediği mal ve hizmetleri üreterek belirli bir kar oranıyla satarak ekonomik sorumluluklarını yerine getirmektedirler. 
Yasal Sorumluluklar: İşletmeler yasal düzenlemeler ile işlerini yürütmekle yükümlüdürler. İşletmelerin ticari faaliyetlerini belli yasal düzenlemeler çerçevesinde yerine getirilmesi beklenmektedir.

Etik Sorumluluklar: İlk iki kategori etik normları barındırsa da, zorunlu olarak kanunlara göre kodlanmış olmayan ancak yine de toplumun üyeleri tarafından işlenmesi beklenen davranışlar ve faaliyetler vardır. Toplumun yasal gereklilikler üzerinde ve üstündeki iş beklentilerini kapsamaktadır.

İsteğe Bağlı Sorumluluklar (Sosyal Sorumluluklar): Sosyal sorumluluklar olarak da isimlendirilen bu sorumluluklar, işletmelerin içinde bulundukları toplumun çıkarlarını gözetmesi ve toplumun sorunlarına duyarlılık göstermesi olarak ifade edebileceğimiz sorumlulukları kapsamaktadır. Bu amaçla yapılan sosyal sorumluluk projeleri ile topluma karşı duyarlılıklarını ifade etme imkânı bulunmaktadır (Balta Peltekoğlu, 2018: 201). Günümüzde şirketler faaliyet gösterdikleri toplumların sorunlarına duyarlılıklarını gösterebilecek sosyal sorumluluk projeleri gerçekleştirerek hedef kitleleri nezninde olumlu imaj oluşturma çabası içinde olduğunu söylemek mümkündür.

\section{KURUMSAL SOSYAL SORUMLULUK UYGULAMA ALANLARI}

Sosyal sorumluluğa dayalı halkla ilişkiler uygulamaları ve kurumsal sosyal sorumluluk anlayışıyla hareket eden işletmelerin, yalnızca kendi faaliyet alanlarında değil, öncelikli toplumsal sorunların çözümünde de rol oynayarak, iyi bir kurumsal vatandaş olarak ülke kalkınmasında etkili rol oynayabileceklerini söylemek mümkündür. Günümüz yoğun rekabet şartlarında işletmelerin zorunlu sorumluluklarını yerine getirmesi yeterli olmamakta, toplumsal beklentileri karşılayabilmek, rekabet gücünü koruyabilmek ve sürdürülebilirliği sağlayabilmek için "gönüllü yükümlülüklerini” de yerine getirmesi önemli görülmektedir (Peltekoğlu ve Tozlu, 2017: 8). Bu nedenden dolayı işletmeler hedef kitleleriyle güvene dayalı iletişim kurabilmek ve bu iletişimi sürdürülebilir kılmak için birçok alanda sosyal sorumluluk projeleri gerçekleştirmektedir.

Sosyal sorumluluğun uygulama alanı oldukça geniştir. Çalışanlardan tedarikçilere kadar, tüm paydaşları kapsayan bir alana sahip olan sosyal sorumluluk, şirketlerin muhatap olarak sorumluluk duymakla yükümlü olduğu geniş bir alan olduğunu ifade etmek mümkündür. Ekoloji ve çevre, tüketici, toplumsal gereksinim ve toplumsal katkı, kamu kurumları ile iyi ilişkiler geliştirme, gönüllülük, çalışanlarla ilişkiler, ortaklarla ilişkiler, ekonomik faaliyetler, patent kullanımının sınırlandırılması, haber ajansları ve iletişim araçlarına karşı sorumluluk olarak siralanmaktadır (Peltekoğlu, 2018: 204-205). Kurumsal sosyal sorumluluk alanları, çalışanlar, müşteriler, toplum, bölgesel kalkınma, uluslararası toplum, yatırımcılar, tedarikçiler, sivil toplum kuruluşları, rakipler ve devlet ve yerel yönetimler olarak sıralanmaktadır. Bu alanları kapsayan birçok kampanya hayata geçirilmektedir (Coşkun, 2010: 59).

Çalışanlar için sosyal sorumluluk faaliyetleri, herhangi bir ayrım yapılmaksızın herkese eşit muamele edilmesi, tüm sosyal haklarından faydalanılmasının sağlanması ve güvenli koşulların yerine getirilmesinin yanı sıra mesleki gelişimini desteklemeye yönelik politikaları içermektedir. Müşteriler, garanti, uygun fiyatlandırma ya da müşterileri yanıltıcı herhangi bir bilginin verilmemesi gibi konuları kapsamaktadır. Gelir dağılımı ve istihdamı destekleyen yatırımlar yapılarak bölgesel kalkınmaya destek verilmesi, böylelikle ilgili bölgelerde yaşan insanların istihdamına katkı sağlanması sosyal sorumluluk açısından önem taşımaktadır.

Yatırımcılar ve ortaklara doğru bilgi paylaşımının yapılması ve şeffaflık politikasının güdülmesi de önemli bir başka konudur. Tedarikçiler sosyal sorumluluk açısından iki farklı öneme sahiptir. Öncelikle üretim açısından önem taşıyan tedarikçilere karşı duyulan sorumluluğun yanı sıra tedarikçinin üretiminin sosyal sorumluluk sınırları içinde olması da önemlidir. Şirketin bir parçası olan tedarikçilerin ürünü üretim biçimleri de önemlidir. Rakiplere yönelik haksız rekabetten kaçınılması, yasa dışı faaliyetler ile rakipleri zor duruma düşürülmemesi gibi konular sosyal sorumluluk için önemlidir. Dolayısıyla işletmelerin iş ahlakı çerçevesinde rekabet etmesi beklenmektedir.

Sivil toplum kuruluşları ile sosyal sorumluluk projelerinde birlikte hareket edilerek, toplumsal sorunlara destek verici faaliyetler gerçekleştirilebilir. Toplumun problemlerinin çözümü için çaba sarfeden bu kuruluşlara nakit bağış ya da hizmet sağlayarak destekler verilebilmektedir. Devlet kurumlarına yönelik sorumluluklar ise, yasal yükümlülüklerin yerine getirilmesi, faaliyet gösterilen ülkelerin mevzuatına uygun hareket edilmesi ve vergilerin ödenmesi gibi sorumlulukları içermektedir.

Kuruluşun faaliyet gösterdiği çevrenin kalkınmasına yönelik faaliyetlerde bulunan bir kurum, kurumsal sosyal sorumluluk alanında genellikle teşebbüs, eğitim, kültür ve sanat ve çevre öğelerini içeren çalışmalar yapmaktadır. Teşebbüs, yatırım faaliyetlerinin arttırılması ve yatırımcıların desteklenmesi sürecidir. Eğitim, gençlerin yaşamlarına katkı sağlayacak faaliyetlerin hayata geçirilmesi, kültür ve sanat faaaliyetleri ile bölgede yaşan insanlarla etkileşim kurabilmek, çevre yaşam kalitesini arttırabilecek ve çevre güvenliğini sağlayabilecek çabaları kapsamaktadır (Okay ve Okay, 2001: 623). 
J. Nelson, sosyal katma değer taşıyan kurumsal sosyal sorumluluk çalışmaları için üç unsure dayanan bir yaklaşımı önermektedir. Bu yaklaşımlar aşağıdaki tabloda yer almaktadır:

Tablo1. Katma Değer Taşıyan Kurumsal Sosyal Sorumluluk Yaklaşımları

\begin{tabular}{|c|c|}
\hline Yaklaşım & Uygulama Biçimi \\
\hline $\begin{array}{l}\text { İşletmenin esas } \\
\text { faaliyetlerinin etkili ve } \\
\text { etik işi }\end{array}$ & $\begin{array}{l}\text { - } \quad \text { Çevresel ve sosyal bakımdan sorumlu kararlar almak. } \\
\text { - Yoksulları göz önünde bulundurarak üretim, dağıtım kaynaklarında } \\
\text { - } \quad \text { Sorumlu yatırımlar gerçekleştirmek. } \\
\text { - } \quad \text { Vergileri ve hak sahipleriplerinin paylaşımın ödemek. } \\
\text { - Sosyal insan kaynağı politikalarını uygulamak. } \\
\text { - } \quad \text { Uluslararası kabul edilen işletme standartlarını uygulamak. } \\
\text { - Teknoloji işbirliğini desteklemek. }\end{array}$ \\
\hline $\begin{array}{l}\text { Sosyal yatırım ve } \\
\text { hayırseverlik }\end{array}$ & $\begin{array}{l}\text { - Geniş düzeyde işletmenin bulunduğu bölgeye eğitim programları sunmak. } \\
\text { - Sosyal veya hayır işleriyle bağlantılı girişimler için çalışanların gönüllü } \\
\text { olarak programlar yapmasını sağlamak. } \\
\text { - } \quad \text { Işletme eğitim projeleri düzenlemek. } \\
\text { - } \quad \text { Bölgenin sağlık projelerini desteklemek. } \\
\text { - } \quad \text { Bölgenin gelişimini destekleyen sponsorluklar yapmak. } \\
\text { - } \quad \text { Mobilizasyon ve şehirle ilgili gelişmelere kaynak ayırmak. }\end{array}$ \\
\hline $\begin{array}{l}\text { Kamu politikas1 } \\
\text { tartışmasına katkıda } \\
\text { bulunmak }\end{array}$ & $\begin{array}{l}\text { - Sorumlu yabancı yatırım ve özel sektörün gelişimi için ortaya çıkan } \\
\text { engelleri kaldırmak. } \\
\text { - Eğitim, kurs, yerel ekonomik gelişim, çalışma ve çevre yönetimi gibi } \\
\text { alanlarda çerçeveler ve sosyal ve çevreyle ilgili politikalara katkıda } \\
\text { bulunmak. } \\
\text { - İnsan hakları standartlarını ve bozulma karşıtı girişimleri de kapsayan iyi } \\
\text { yönetimi desteklemek. }\end{array}$ \\
\hline
\end{tabular}

Kaynak: (akt.Okay ve Okay, 2001: 624)

"Kuruluşların sosyal sorumluluk anlayışları kapsamında topluma karşı sorumluluklarını nasıl belirleyeceği, öncelikleri hangi alanlara vereceği konusundaki araştırmalar ve bunun sonucunda ortaya çıkan önerileri kuruluşun yönetimine götürme ve sebepleri ile ikna etme görevini halkla ilişkiler yönetimi taşımaktadır. Önerilen aktiviteler arasından kuruluşun genel politikasına en uygun olan seçilmeli, plan ve programa dayalı olarak hedef kitlelere aktarılmalıdır" (Göksel vd. Akt. Göztaş ve Baytekin, 2009: 2008-2009). Halkla ilişkiler yönetiminin yönledirmesi ile kurumun felsefesine dahil edilen kurumsal sosyal sorumluluk anlayışı, kurumun hedef kitlesine kendisini ifade edebilme özelliğini de taşıyabilmelidir. Bu nedenle toplumun ihtiyaçlarına karşıllk gelen projeleri hayata geçirmek önemlidir.

Günümüz yönetim anlayışında, sosyal sorumluluk iş etiği ile doğru orantılı olarak görülmektedir. İşletmenin toplumsal bir kişilik olarak kabul edildiği günümüz yönetimlerinde, çalışanların da iç müşteri olarak değerlendirilmektedir. Bu yönetim anlayışında toplam kalite, öğrenen örgütler, katılımcı yönetim, kurum kültürü ve kimliği, kurumsal imaj gibi konulardan bahsedilmektedir. İşletmenin toplumsal kişiliğinin kabul edildiği yaklaşımda, davranışlar ve iletişim, halkla ilişkiler yönetiminin yükümlülüğündedir. Halkla ilişkiler yönetimi işletmelerin sosyal sorumluluk algısı ve planlamasında önemli bir role sahiptir. Gönüllüler, işgören, müşteriler, yatırımcılar başta olmak üzere geniş kitlelere ulaşma amacıyla hareketle sosyal sorumluluk kampanyalarının iletişim kampanyası olarak kurgulanması sebebiyle halkla ilişkiler yönetimi sorumluluğundadır (Göztaş ve Baytekin, 2009: 2008-2009). İşletmelerin planlanan kurumsal sosyal sorumluluk projelerini dört farklı perspektiften ele almak mümkündür. Bu sorumluluklar; çevre, sağlık, eğitim, kültür-sanat, olarak sıralanabilir. 
Çevre: Hem üretim sürecinde hem de çevre ve çevrenin ekolojik yapısını korumaya yönelik bir yaklaşımı ifade etmektedir. Çevre kamusal alan olarak, işletmelerin sosyal sorumluluk alanına girmektedir. Bu bağlamda çevreye yönelik kurumsal sosyal sorumluluk projeleri gerçekleştirerek doğal kaynakları korumak ve çevre kirliliğini engellemeye çalışmak gibi sorumlulukları üstlenmektedirler (Coşkun, 2010: 68).

Bu kategori altında Kotler'in "sosyal açıdan sorumluluk taşıyan iş uygulamaları" olarak ifade ettiği Dell Markasının "Çevre Programı için Tasarım” projesi örnek olarak gösterilebilir. 2003 yılında Dell Çevre Raporu ile marka, "Çevre için Tasarım" atağı yaparak; ürün tasarımında ürün yaşam süresini arttırmak, enerji tüketimin azaltmak, çevreye duyarlı malzeme kullanımı sağlamak, üretimde malzeme azaltımına teşvik ve yüksek seviyede dönüşümlü ürün kullanımının arttırılmasını sağlayacaklarını ifade etmektedir (Kotler ve Lee, 2006: 38). Dell markası üretim sürecinde çevreci anlayışı benimseyerek ve iş uygulamalarını çevreye duyarlı olarak dizayn ederek sosyal sorumluluğun çevre boyutunu ortaya koymaktadır. İşletmelerin üretim faaliyetlerini çevreye en az zararı verecek biçimde tasarlaması sosyal sorumluluğun önemli bir ayağını oluşturduğunu söylemek mümkündür.

Sağlık: Sosyal sorunlarla ilgilenmek, faaliyet gösterilen ülkelerin özelliklerine göre değiş̧iklikler gösterebilmektedir. Kimi zaman hükümet yatırımları yeterli olmamakta bu nedenle özel sektörün sosyal sorunlara kaynak sağlaması gerekmektedir. Yapılan sosyal sorumluluk faaliyetleri toplumun ihtiyaçlarına yanıt verirken kamouyunda da olumlu karşılanmaktadır (Akay ve Akay, 2001: 640-641). Bu nedenle işletmeler toplumun ihtiyaçları doğrultusunda eksiklikleri giderebilmek için sosyal sorumluluk çalışmaları gerçekleştirmektedirler. Sağlık alanında var olan eksiklikleri kapatabilmek için birçok sosyal sorumluluk projesi yapılmaktadır.

Aygaz'ın Ay Işığı Projesi ile toplumun sağlık hizmetlerinden daha rahat koşullarda faydalanması ve bu faydanın sürdürülebilir olması amacıyla gerçekleştirdiği projede, 2006 yılında T.C. Sağlık Bakanlığı ile imzalanan protokole göre, 81 ilde 81 Sağlık Ocağı'nın Aşı Odasını yenilemek hedeflenmektedir. Aşı odalarında her türlü iç bakımı yapmak, gerekli malzemeleri temin etmek ve odaların standartlarını yükseltmek amaçlanmıştır (sosyal sorumluluk platformu, 2016). Sağlık alanında yapılan birçok proje ile birlikte toplumun yaşam koşullarının daha iyi hale getirilmesi hedeflenmektedir. Bu sayede hem toplumsal sorunlara çözüm bulunmakta hem de markanın sosyal sorumluluğa verdiği önem pekiştirilmektedir.

Eğitim: Toplumun işletmelerin iyi birer kurumsal vatandaş olma beklentisine karşılamak için hayırseverlik anlayışı doğrultusunda, insan refahını veya iyi niyetini teşvik etmek üzere eğitim alanında aktif olarak eylemlere veya programlara dahil olmak sosyal sorumluluk anlayışı kapsamındadır (Carroll, 1991: 42). Kurumlar faaliyet gösterdikleri ülkelerin ihtiyaçları doğrultusunda eğitim faaliyetlerine destek vermekte ve iyi niyetlerini gösterebilme olanağı bulunabilmektedir. Toplum yararına gerçekleştirilen bu projeler hedef kitle üzerinde iyi izlenimler yaratabilmektedir. Bu nedenle eğitim alanında köklü projeler gerçekleştirilmektedir.

Bu projlerden biri Doğan Gazetecilik tarafından 23 Nisan 2005'te Hanzade Doğan Boyner' in önderliğinde başlatılan "Baba Beni Okula Gönder (BBOG)" projesidir. Kız çocuklarının eğitim olanaklarından yararlanabilmesini sağlamak amacıyla başlatılan proje ile 10 yılda yaklaşık 35 Milyon TL bağış, 300 bin'den fazla bireysel bağış̧̧ı, 33 yurt, 12 okul, $10.500 \mathrm{kız} \mathrm{çocuğuna} \mathrm{burs} \mathrm{desteği} \mathrm{ile} \mathrm{sürdürülebilir} \mathrm{bir} \mathrm{projedir.} \mathrm{Yapılan}$ etki araştırması sonuçlarına göre toplum nezdinde \%75'lik bir kesim tarafından başarılı bulunan proje birçok gönüllü bularak uzun yıllar devam etmektedir (Miraç, 2015). Etki araştırması verileri ile başarılı projelerin toplum tarafından destek gördüğü ve ilgi çektiğini söylemek mümkündür.

Kültür-Sanat: İ̧̧letmeler toplumsal gelişmeyi arttırmak ve birlik beraberliğe katkı sağlamak için kültürel ve sanatsal faaliyetlerin arttırılması ve geliştirilmesi adına sosyal sorumluluk projeleri yapmakta ya da var olan bir projeye destek vermektedir. Konserler, bale, tiyatro gösterileri, festival ve şenlikler işletmelerin yaptığ 1 projelerin başlıcalarıdır. Bunun yanı sıra tarihi konularda da projeler gerçekleştirilmektedir (Coşkun, 2010:74). Böylelikle kültürel mirasın aktarımına katkı sağlanmaktadır. Bu alanda yapılan kurumsal sosyal sorumluluk projelerine örnek olarak uzun soluklu ve sürdürülebilir projeler olarak Eti Çocuk Tiyatrosu ve Opet Tarihe Sayg1 Projesi verilebilir.

\section{HALKLA ILIŞKILER BAĞLAMINDA KSS PROJELERININ AVANTAJLARI: KURUMSAL IMMAJ VE KURUMSAL ITTI BAR}

Toplumun refahını arttırmak amacıyla, iç kaynakların kullanımı ve gönüllü kurumsal uygulamaların gerçekleştirilmesi olarak tanımlanan kurumsal sosyal sorumluluk (Kotler vd., 2012:14), kurumların itibarını güçlendirici bir nitelik taşıyarak, kuruma yönelik güven oluşturmakta ve kurumun yüksek kalitede algılanmasını sağlayarak, saygınlığı arttırmaktadır (Coşkun, 2010:101). Kurumsal sosyal sorumluluk projeleri kurumlara yönelik olumlu imaj oluşturarak ve saygınlık sağlayarak uzun vadede itibara dönüşebilmektedir. 
Markaların konumlandırılmasında etkili olan kurumsal sosyal sorumluluk projeleri, markaların müşterilerin zihninde bir yer edinmesinde avantaj oluşturmaktadır. Özellikle rekabetin yükssek olduğu alanlarda hedef kitlelerin tercihleri üzerinde etkili olabilmektedir. Kotler ve Amstrong, "rakip ürünler ile karşılaştırıldığında, müşterilerin o ürün için sahip oldukları algılamalardan, izlenimlerden ve hislerden oluşan karmaşı bir küme" olarak tanımlandırdığı marka konumlandırma ile marka tercihleri üzerinde etkin olmaktadır. (Kotler, 2006: 118). Markaların konumlandırmasına ve marka tercihine katkısı olan kurumsal sosyal sorumluluk projeleri markaların imajları üzerinde olumlu yansımaktadır. Gerçekleştirilen projelerle marka imajına olumlu olarak yansımaktadır.

Kurumsal sosyal sorumluluk projelerinin, kurum imajına olumlu etki yarattığını hazırlanan raporlar üzerinden görmek mümkündür. Örnek olarak Fortune dergisi, HayGroup tarafinda yürütülen 10.000 yönetici ve analiz sonucunda oluşturulan Amerikanın en fazla hayranlık duyulan şirketleri listesini hazırlarken kullanılan ölçekte şirketlerin sekiz nitelik üzerinden puanlandırılması gerçekleştirilmektedir. Bu nitelikler, yenilenme, finansal sağlamlık, çalışanların yeteneği, kurum varlıklarının kullanımı, uzun vadeli yatırım değeri, yönetim kalitesi, ürünler/hizmetlerin kalitesi ve sosyal sorumluluk olarak belirlenmiştir. Bu nedenle toplumda sağlam bir ün ve kriz esnasında gerçek bir servet olarak sosyal sorumluluğu göstermek mümkündür (Kotler ve Lee, 2006: 14-15). Tüm bunların ötesinde kurumsal sosyal sorumluluk projeleri reklam desteği olarak da kurumlara katkı sağlamaktadır. Bir projenin hayata geçirilmesi ve duyurulması sürecinde medyada yer alan marka, akıllarda kalıcı olabilmektedir.

Bir diğer avantaj ise, maliyetlerle ilgilidir. Gerek iş uygulamalarında gerekse sosyal sorumluluğu teşvik eden uygulamalar maliyetlerin azaltılmasında etkin olmaktadır. Kotler ve Lee (2006:17) bağış ve teşviklerin işletmelerin maliyetlerini düşürdügünü ifade ederken, atıkların azaltılması, malzemelerin geri dönüştürülmesi, su ve elektirik tasarrufunun sağlanması gibi çevresel girişimlerin şirketlerin maliyetlerine de yansıdığını belirtmektedir. Polonsky ve Jemons, marka ile sosyal sorumluluğun bir bütün içinde olduğunu ve marka değeri ve kişiliği geliştirerek pazarda farklılaştırma sağlandığını vurgulamaktadır. İş dünyası için önemli bir uygulama olan sosyal sorumluluk projelerinin marka imaj1 üzerindeki etkisi üzerine 2001 yılında gerçekleştirilen ve 20 gelişmiş ülkede yapılan bir araştırmaya göre marka imajına etkisi \% 49 oranında çıkmıştır (akt.Özdemir, 2009:66). Markalaşma ve imajın her geçen gün artan önemi de göz önünde bulundurulduğunda, günümüzde bu oranın daha da yüksek olabileceğini söylemek mümkündür. Böylelikle yapılan sosyal sorumluluk projelerinin paydaşlar üzerinde olumlu bir imaj yarattığını söylenebilir. Ayrıca bireylerin markaları/kurumları değerlendirirken kurumsal sosyal sorumluluk projelerine sağladıkları katkıları görmezden gelmedikleri ve marka/kurum tercihlerinde bu projelerin önemli bir yer tuttuğunu da ifade edilebilir.

\section{ARAŞTIRMA}

\subsection{Araştırmanın Amacı}

Araştırmada nitel ve nicel yöntem kullanılmıştır. Literatür araştırmasının ardından araştırma gerçekleştirilmiştir. $\mathrm{Bu}$ araştırmada, meslek yüksekokulu öğrencilerinin kurumsal sosyal sorumluluk projelerine yönelik algıSı analiz edilmiştir. Araştarma kapsamında aşağıdaki sorulara yanıt aranmıştır:

1. MYO öğrencilerinin KSS projelerinin türlerine yönelik yaklaşımları nasıldır?

2. MYO öğrencilerinin KSS projelerinin inandırıcılığına yönelik yaklaşımı nasıldır?

3. MYO öğrencilerinin KSS projelerine yaklaşımlarında okudukları programlar anlamlı fark yaratır mı?

4. MYO öğrencilerinin KSS projelerine yönelik yaklaşımında cinsiyet önemli midir?

5. MYO öğrencileri KSS projelerinde görev almak ister mi?

6. MYO öğrencileri KSS projelerinde görev alma durumu cinsiyete göre farkl11ık gösterir mi?

\subsection{Araştırmanın Evreni ve Örneklemi}

Basit rastlantısal örneklem yöntemi ile seçilen 250 kişi ile gerçekleştirilen çalışmanın örneklemi, bir MYO'nun 5 farklı programında eğitim gören birinci ve ikinci sınıf öğrencileri arasından seçilmiştir.

\subsection{Araştırmanın Veri Toplama Aracı}

$\mathrm{Bu}$ araştırma nicel araştırma yöntemlerinden yüz yüze anket modeli kullanılarak gerçekleştirilmiştir. Anket uygulaması yüz yüze gerçekleştirilmiştir. Anket soruları 5'li likert yöntemine göre tasarlanmıştır. Araştırmada veri toplama yönteminde uygulanan KSS projelerinin türlerine yer verilmiştir. Çevre, sağlık, eğitim, kültür, sanat gibi KSS projelerinin uygulamalarının MYO öğrencileri tarafından nasıl algılandığını ortaya koymak için bu çalışma gerçekleştirilmiştir. 


\subsection{Araştırmanın Yöntemi}

Verilerin analizi SPSS 22 programı ile yapılmış ve $\% 95$ güven düzeyi ile çalışılmıştır. Analizlerde kişisel bilgiler için frekans dağılımı verilmiştir. İfadeler için katılım düzeyi ve ortalaması hesaplanmıştır. İfadelere katılım düzeylerinin cinsiyete ve sinıfa göre farklılık gösterme durumu Mann Whitney, okunulan programa göre farkl1l1k gösterme durumu ise Kruskal Wallis testi ile analiz edilmiştir.

\subsection{Araştırmanın Sınırlılıkları}

Araştırmanın gerçekleştirildiği yüksek okulun mevcut programları ve burada eğitim gören öğrencilerin kurumsal sosyal sorumluluk projelerine yönelik yaklaşımlarını anlamak ile araştırma sınırlandırılmıştır. Araştırma spesifik projeler üzerine yönledirilmemiş ve kurumsal sosyal sorumluluk projelerine genel bir yaklaşım olarak değerlendirilmiştir. Bu nedenle projeler marka ve/veya firma bazlı olarak araştırmaya dahil edilmemiştir.

\subsection{Araştırma Bulguları ve Sonuç}

Araştırmada gerçekleştirilen anket iki bölümden oluşmaktadır. İlk bölümde, araştırmaya katılanların demografik özelliklerini ortaya çıkarabilmek amacıyla, cinsiyet, eğitim, gelir durumu, okuduğu program ve okuduğu sınıf yer almaktadır. Ikinci bölümde ise kurumsal sosyal sorumluluk projelerine yönelik algılarını ortaya çıkartacak sorular yer almaktadır.

\section{Tablo2: Örneklemin Profili}

\begin{tabular}{|c|c|c|c|}
\hline & & $\mathrm{n}$ & $\%$ \\
\hline \multirow{4}{*}{ Yaş } & $17-18$ & 51 & 22,6 \\
\hline & $19-20$ & 126 & 55,8 \\
\hline & $21-22$ & 28 & 12,4 \\
\hline & 23 ve üzeri & 21 & 9,3 \\
\hline \multirow{2}{*}{ Cinsiyet } & Erkek & 104 & 46,0 \\
\hline & Kadın & 122 & 54,0 \\
\hline \multirow{5}{*}{ Gelir Durumu } & 1000 TLden az & 93 & 41,2 \\
\hline & $1001-2000 \mathrm{TL}$ & 67 & 29,6 \\
\hline & 2001-3000 TL & 36 & 15,9 \\
\hline & $3001-4000 \mathrm{TL}$ & 20 & 8,8 \\
\hline & 4000 TLden fazla & 10 & 4,4 \\
\hline \multirow{2}{*}{ Sinif } & $1 . \sin 1 f$ & 139 & 61,5 \\
\hline & $2 . \sin 1 f$ & 87 & 38,5 \\
\hline \multirow{5}{*}{ Program } & Büro yönetimi ve yönetici asistanlığ & 30 & 13,3 \\
\hline & Hakla ilişkiler ve Tanıtım & 62 & 27,4 \\
\hline & İş Sağlığı ve Güvenliği & 53 & 23,5 \\
\hline & Lojistik & 34 & 15,0 \\
\hline & Sivil Savunma ve İtfaiyecilik & 47 & 20,8 \\
\hline
\end{tabular}


Katılımcılardan 19-20 yaşında olanların oranı \%55,8 (n: 126); kadınların oranı \%54,0 (n: 122); geliri 1000 TLden az olanların oranı \%41,2 (n: 93); 1.sınıf olanların oranı \%61,5 (n: 139); Hakla İlişkiler ve Tanıtım okuyanların oranı \%27,4'tür (n: 62).

Tablo 3: Kurumsal Sosyal Sorumluk Projelerinin Türlerine Yönelik Katılım Düzeyleri

\begin{tabular}{|c|c|c|c|c|c|c|c|c|c|c|c|}
\hline & \multicolumn{2}{|c|}{$\begin{array}{c}\text { Kesinlikle } \\
\text { Katılmıyorum }\end{array}$} & \multicolumn{2}{|c|}{ Katılmiyorum } & \multicolumn{2}{|c|}{ Kararsızım } & \multicolumn{2}{|c|}{ Kat1liyorum } & \multicolumn{2}{|c|}{$\begin{array}{c}\text { Kesinlikle } \\
\text { Katıliyorum }\end{array}$} & \multirow{2}{*}{ Ortalama } \\
\hline & $\mathrm{n}$ & $\%$ & $\mathrm{n}$ & $\%$ & $\mathrm{n}$ & $\%$ & $\mathrm{n}$ & $\%$ & $\mathrm{n}$ & $\%$ & \\
\hline $\begin{array}{l}\text { Eğitim alanında yapılan } \\
\text { kurumsal sosyal sorumluluk } \\
\text { projelerinin öncelikli olması } \\
\text { gerekir }\end{array}$ & 2 & ,9 & 2 & ,9 & 35 & 15,5 & 54 & 23,9 & 133 & 58,8 & 4,39 \\
\hline
\end{tabular}

Türkiye'nin sağlık alanında

Kurumsal sosyal

sorumluluk projesi

$2 \quad 9 \quad 1 \quad, 4$

$29 \quad 12,8 \quad 48$

$21,2 \quad 146 \quad 64,6$

4,48

yapmaya ihtiyacı var

Türkiye'nin eğitim alanında

Kurumsal sosyal

sorumluluk projesi

1

$1 \quad, 4$

,4 3

$3 \quad 1,3 \quad 16$

$7,1 \quad 48$

$21,2 \quad 158$

69,9

4,59

yapılmasına ihtiyacı var

Türkiye'de toplumsal meselelere yönelik (kadına şiddet, kız çocuklarının okula yollanmamas1, istismar vb) konularda şirketler yeteri kadar sorumluluk almamaktadır

Sağlık alanında yapılan kurumsal sosyal sorumluluk Projelerinin öncelikli olması 0 6 $2,7 \quad 4 \quad 1,8$ $29 \quad 12,8 \quad 48$ 21,2 139 61,5 gerekir

Araştırmanın 1. sorusu, MYO öğrencilerinin KSS projelerine yaklaşımları sorgulanmaktadır: Yanıtlar tablo 2 'de yer alan veriler aşağıdaki gibidir:

Türkiye'nin eğitim alanında kurumsal sosyal sorumluluk projesi yapılmasına ihtiyacı vardır görüşüne katılımcıların \%69,9’u (n: 158) kesinlikle katılıyorum yanıtını vermiştir.

Sağlık alanında yapılan kurumsal sosyal sorumluluk projelerinin öncelikli olması gerekir diyenlerin oranı $\% 62,8$ (n: 142) dir.

"Türkiye'de toplumsal meselelere yönelik (kadına şiddet, kız çocuklarının okula yollanmaması, istismar gibi) konularda şirketler yeteri kadar sorumluluk almamaktadır" diyenlerin oranı \%61,5 (n: 139) dir.

Çevre alanında kurumsal sosyal sorumluluk projelerinin daha fazla yapılması gereklidir \% 60,6 (n: 137) kesinlikle katılıyorum yanıtını vermiştir.

Elde edilen veriler 1şı̆̆ında kurumsal sosyal sorumluluk projelerinde öncelik sırası, eğitim, sağlık, toplumsal meseleler ve son olarak çevre olmak üzere sıralanmaktadır. Katılımcılar en fazla eğitim alanında projelerin olmasını gerektiğini ifade ederken, en az düşük puanlamayı çevre ile ilgili projeler almıştır. 
Tablo 4: KSS Projeleri’nin inandırıcılıklarına Yönelik Yaklaşımların Katılım Düzeyi ve Ortalaması

\begin{tabular}{|c|c|c|c|c|}
\hline $\begin{array}{l}\text { Kesinlikle } \\
\text { Katılmıyorum }\end{array}$ & Katılmıyorum & Kararsızım & Katıliyorum & $\begin{array}{l}\text { Kesinlikle } \\
\text { Kat1liyorum }\end{array}$ \\
\hline
\end{tabular}

Ortalama

$\begin{array}{lllllllllll}\mathrm{n} & \% & \mathrm{n} & \% & \mathrm{n} & \% & \mathrm{n} & \% & \mathrm{n} & \%\end{array}$

Eğitim alanında yapılan

Kurumsal sosyal sorumluluk projelerini

94,0

5,3

$61 \quad 27,0 \quad 72$

31,9

72

31,9

3,82

inandırıcı bulurum

Kurumlar çevre ile ilgili

kurumsal sosyal sorumluluk

projesi yaptığında bunu

$\begin{array}{llll}6 & 2,7 & 11 & 4,9\end{array}$

$4,9 \quad 53$

23,5

89

39,4

67

29,6

3,88

inandirici bulurum

Kurumların çevre ile ilgili

Kurumsal sosyal

sorumluluk projesi yapmas1

65

$28,8 \quad 40$

17,7

46

20,4

39

17,3

15,9

2,74

beni şüpheye düşürür

İşletmeler çevre ile ilgili

KSS projesi yaptığında çevreyi kirlettiği ve bu açığı

$11,9 \quad 32$

14,2

kapadığını düşünürüm

Bir kurumsal sosyal

sorumluluk projesi

pazarlama amacı güderse

$9 \quad 4,0$

17

7,5

64

28,3

45

19,9

91

40,3

3,85

inandırıcı bulmam

Bir Kurumsal sosyal sorumluluk projesine destek sağlamak satış veya satın

o proje inandırıcı gelmez

Bir davranış oluşturma yada bir davranış geliştirmek için yapılan Kurumsal sosyal

sorumluluk projeler

inandırıcı değildir

Bir kurumsal sosyal sorumluluk projesinin tüm işletme tarafindan kabul görüp görmediği, çalışan ve paydaşlarla birlikte yürütülmesi inandırıcılığı arttırır

Kurumların kendi menfaatleri doğrultusunda kurumsal sosyal sorumluluk 14 6,2 17 7,5 86 projesi yaptığını düşünürüm

6,2


Araştırmanın 2. sorusu, MYO öğrencilerinin KSS projelerinin inandırıcılığına yönelik yaklaşımları nasıldır? Sorusuna yönelik oranlar aşağıdaki gibidir:

Eğitim alanında yapılan Kurumsal sosyal sorumluluk projelerini inandırıcı bulurum, diyen katılımcılar $\% 73,8$ (n: 144) ile en fazla inandırıcı bulunan projeler olarak görülmektedir.

Kurumlar çevre ile ilgili kurumsal sosyal sorumluluk projesi yaptığında bunu inandırıcı bulurum \% 69 (n: 156).

Kurumların çevre ile ilgili kurumsal sosyal sorumluluk projesi yapması beni şüpheye düşürür ifadesine \% 46,5 (n: 105) katılmamaktadır, buna karşın \% 33,2 (n: 75) bu ifadeye katılmaktadır. İfade olumsuz olarak sorulmasına karşın öğrencilerin çevre ile ilgili projelere karşı şüpheci davranmadıkları görülmektedir.

"İşletmeler çevre ile ilgili KSS projesi yaptığında çevreyi kirlettiği ve bu açığı kapadığını düşünürüm" ifadesine katılım, \%46,5 (n: 92) iken \%26,1 (n: 26) bu ifadeye katılmamaktadır. Çevre ile ilgili KSS projesi yapılmasıyla şüpheye düşmemelerine rağmen kurumların yaptıkları kurumların çevre kirliliğine sebebiyet verdikleri için KSS projeleri tasarladıklarına inandıkları ifade etmektedirler.

"Bir kurumsal sosyal sorumluluk projesi pazarlama amacı güderse ya da koşullu satış yaparsa inandırıcı bulmam" ifadesine \% 60,2 (n: 136) katılmaktadırlar. Bu veriler doğrultusunda işletmelerin çeşitli koşullara bağlanarak yaptıkları yardımlar ya da KSS projeleri hedef kitle tarafından olumlu karşılanmadığını ifade etmek mümkündür.

"Bir kurumsal sosyal sorumluluk projesine destek sağlamak satış veya satın alma şartına bağlandığında o proje inandırıcı gelmez" ifadesine katılanların oranı \% 57,5 dir (n:130).

"Bir davranış oluşturma ya da bir davranış geliştirmek için yapılan kurumsal sosyal sorumluluk projeleri inandırıcı değildir" ifadesine katılım \% 32,3 (n: 73) iken katılımcıların \%37,6 (n: 85) Davranış geliştirmek için yapılan kurumsal sosyal sorumluluk projelerini inandırıcı bulmaktadır.

"Bir kurumsal sosyal sorumluluk projesinin tüm işletme tarafindan kabul görüp görmediği, çalışan ve paydaşlarla birlikte yürütülmesi inandırıcılığı arttırır" diyenlerin oranı \%69,5 (n:157) iken katılımcıların yalnızca \%3,5 (n: 8) bu ifadeye katılmamaktadır. Bu ifade ile bir KSS projesinin kurumun tümü tarafından kabul gördüğünün hedef kitleye aktarılması bireylerin algısını olumlu etkilemektedir denilebilir. Bu nedenle yapılan projelerin hem çalışanlar hem de paydaşlar ile birlikte yürütülmesi önemlidir.

"Kurumların kendileri menfaatleri doğrultusunda kurumsal sosyal sorumluluk projesi yaptığını düşünürüm” ifadesine katılanların oranı \%48,2 dir (n: 109). Katılımcılar yapılan projelerin şirketlere olumlu yansıdığını düşündüklerini ifade etmek mümkündür.

\section{Tablo 5: KSS Projeleri’nin Türlerine Yönelik İfadelerin Cinsiyet Açısından İncelenmesi}

\begin{tabular}{|c|c|c|c|c|c|}
\hline Cinsiyet & & $\mathrm{n}$ & $\begin{array}{l}\text { Sira } \\
\text { Ort }\end{array}$ & $\mathrm{U}$ & $\mathrm{p}$ \\
\hline \multirow{2}{*}{$\begin{array}{l}\text { Eğitim alanında yapılan kurumsal sosyal sorumluluk projelerinin öncelikli } \\
\text { olması gerekir }\end{array}$} & Erkek & 104 & 110,48 & \multirow{2}{*}{6029,500} & \multirow{2}{*}{,467 } \\
\hline & Kadın & 122 & 116,08 & & \\
\hline \multirow{2}{*}{$\begin{array}{l}\text { Eğitim alanında yapılan Kurumsal sosyal sorumluluk projelerini inandırıcı } \\
\text { bulurum }\end{array}$} & Erkek & 104 & 110,58 & \multirow{2}{*}{6040,500} & \multirow{2}{*}{, 517} \\
\hline & Kadın & 122 & 115,99 & & \\
\hline \multirow{2}{*}{$\begin{array}{l}\text { Sağlık alanında yapılan kurumsal sosyal sorumluluk Projelerinin öncelikli } \\
\text { olması gerekir }\end{array}$} & Erkek & 104 & 102,17 & \multirow{2}{*}{5165,500} & \multirow{2}{*}{, $005^{*}$} \\
\hline & Kadın & 122 & 123,16 & & \\
\hline \multirow{2}{*}{$\begin{array}{l}\text { Türkiye'nin sağlık alanında Kurumsal sosyal sorumluluk projesi yapmaya } \\
\text { ihtiyacı var }\end{array}$} & Erkek & 104 & 109,00 & \multirow{2}{*}{5876,000} & \multirow{2}{*}{,260 } \\
\hline & Kadın & 122 & 117,34 & & \\
\hline \multirow{2}{*}{$\begin{array}{l}\text { Çevre alanında Kurumsal sosyal sorumluluk projelerinin daha fazla } \\
\text { yapılması gereklidir }\end{array}$} & Erkek & 104 & 112,48 & \multirow{2}{*}{6237,500} & \multirow{2}{*}{,802 } \\
\hline & Kadın & 122 & 114,37 & & \\
\hline
\end{tabular}


Türkiye'nin eğitim alanında Kurumsal sosyal sorumluluk projesi yapılmasina ihtiyacı var

$\begin{array}{lrrrr}\text { Erkek } & 104 & 110,97 & & \\ \text { Kadın } & 122 & 115,66 & 6080,500 & , 504 \\ \text { Erkek } & 104 & 113,27 & & \\ & & & 6320,500 & , 958 \\ \text { Kadın } & 122 & 113,69 & & \end{array}$

Kurumsal sosyal sorumluluk projelerinin çevre alanında daha fazla yapılması gerekir

Erkek $104 \quad 104,92$

Türkiye'de toplumsal meselelere yönelik (kadına şiddet, kız çocuklarının okula yollanmaması, istismar gb) konularda şirketler yeteri kadar sorumluluk almamaktadır

Kadın $122 \quad 120,815452,000 \quad, 036^{*}$

Toplumsal meselelerin çözümünde Kurumsal sosyal sorumluluk projelerinin önemi fazladır

Erkek $104 \quad 116,98$

Kadın $122 \quad 110,54 \quad 5982,500 \quad, 429$

\begin{tabular}{lrrrr}
\hline $\begin{array}{l}\text { Kültür Sanat alanında yapılan Kurumsal sosyal sorumluluk projeleri } \\
\text { yeterlidir }\end{array}$ & Erkek 104 & 124,70 & $5179,000,015^{*}$ \\
& Kadın 122 & 103,95 & \\
\hline $\begin{array}{l}\text { Kültür sanat alanında yapılan Kurumsal sosyal sorumluluk projelerinin çok } \\
\text { öncelikli olması gerekmez }\end{array}$ & Erkek 104 & 126,52 & \\
& Kadın 122 & 102,40 & 4990,000 &, $005^{*}$ \\
\hline
\end{tabular}

p*<0,05

Araştırmanın 3. sorusu, MYO öğrencilerinin KSS projelerine yaklaşımında cinsiyetleri anlamlı bir fark yaratır mı? sorusuna yönelik oranlar aşağıdaki gibidir:

"Sağlık alanında yapılan kurumsal sosyal sorumluluk projelerinin öncelikli olması gerekir" ifadesine katılım cinsiyete göre farklılık göstermektedir $(\mathrm{p}<0,05)$. Kadınların "sağlık alanında yapılan sosyal sorumluluk projelerinin öncelikli olması gerekir” ifadesine katılımı erkeklere oranla daha yüksektir.

"Türkiye'de toplumsal meselelere yönelik (kadına şiddet, kız çocuklarının okula yollanmaması, istismar vb) konularda şirketler yeteri kadar sorumluluk almamaktadır" ifadesine katılım cinsiyete göre farklılık göstermektedir $(\mathrm{p}<0,05)$. Kadınların ifadeye katılım düzeyleri erkek katılımcılara göre daha yüksek olduğu görülmektedir.

"Kültür-sanat alanında yapılan kurumsal sosyal sorumluluk projeleri yeterlidir" ifadesine katılım cinsiyete göre farklılık göstermektedir $(\mathrm{p}<0,05)$. Erkek katılımcıların bu ifadeye katılım oranı kadınlara oranla daha yüksektir. Elde edilen bulgular sonucu kadın katılımcıların kültür-sanat alanında yapılan kurumsal sosyal sorumluluk projelerini yeterli görmedikleri görülmektedir.

"Kültür-sanat alanında yapılan kurumsal sosyal sorumluluk projelerinin çok öncelikli olması gerekmez" ifadesine katılım cinsiyete göre farklılık göstermektedir $(\mathrm{p}<0,05)$. Erkek katılımcılar kültür-sanat alanında yapılan çalışmaların öncelikli olması gerekmediği ifadesine katılımları kadın katılımcılara oranla daha yüksektir.

Tablo 6: Cinsiyete Göre KSS Projelerine Yönelik Güvene İlişkin İfadelerin İncelenmesi

\begin{tabular}{|c|c|c|c|c|c|}
\hline Cinsiyet & & $\mathrm{n}$ & $\begin{array}{l}\text { Sira } \\
\text { Ort }\end{array}$ & $\mathrm{U}$ & $\mathrm{p}$ \\
\hline \multirow{2}{*}{$\begin{array}{l}\text { Kurumlar çevre ile ilgili kurumsal sosyal sorumluluk projesi yaptığında } \\
\text { bunu inandırıcı bulurum }\end{array}$} & Erkek & 104 & & \multirow{2}{*}{6181,500} & \multirow{2}{*}{,727 } \\
\hline & Kadın & 122 & 112,17 & & \\
\hline \multirow{2}{*}{$\begin{array}{l}\text { Kurumların çevre ile ilgili Kurumsal sosyal sorumluluk projesi yapması } \\
\text { beni şüpheye düşürür }\end{array}$} & Erkek & 104 & 127,92 & \multirow{2}{*}{4844,500} & \multirow{2}{*}{, $002 *$} \\
\hline & Kadın & 122 & 101,21 & & \\
\hline & Erkek & 104 & 122,90 & 5366,500 &, $040 *$ \\
\hline
\end{tabular}


İşletmeler çevre ile ilgili KSS projesi yaptığında çevreyi kirlettiği ve bu açığı kapadığını düşünürüm

Bir kurumsal sosyal sorumluluk projesi pazarlama amacı güderse yada koşullu satış yaparsa inandırıcı bulmam

Bir Kurumsal sosyal sorumluluk projesine destek sağlamak satış veya satın alma şartına bağlandığında o proje inandırıcı gelmez
Kadın $122 \quad 105,49$

\begin{tabular}{lllll} 
Erkek & 104 & 121,08 & & \\
Kadın & 122 & 107,04 & 5555,500 &, 090 \\
Erkek & 104 & 125,24 & & \\
Kadın & 122 & 103,49 & & \\
\hline Erkek & 104 & 127,50 & & \\
\hline Kadın & 122 & 101,57 & & \\
\hline Erkek & 104 & 119,23 & & \\
\hline Kadın & 122 & 108,62 & & \\
\hline Erkek & 104 & 118,73 & & \\
\hline Kadın & 122 & 109,04 & & \\
\hline
\end{tabular}

Bir davranış oluşturma yada bir davranış geliştirmek için yapılan Kurumsal sosyal sorumluluk projeleri inandırıcı değildir

Bir kurumsal sosyal sorumluluk projesinin tüm işletme tarafindan kabul görüp görmediği, çalışan ve paydaşlarla birlikte yürütülmesi inandırıcılığı arttırır

Kurumların kendileri menfaatleri doğrultusunda kurumsal sosyal sorumluluk projesi yaptığını düşünürüm

\section{$\mathbf{p}^{*}<0,05$}

Araştırmanın 3. sorusu, MYO öğrencilerinin KSS projelerinin inandırıcılığına yönelik yaklaşımında cinsiyetleri anlamlı fark yaratır mı?:

"Kurumların çevre ile ilgili kurumsal sosyal sorumluluk projeleri yapması beni şüpheye düşürür" ifadesine katılım cinsiyete göre farkl1lık göstermektedir $(\mathrm{p}<0,05)$. Bu ifadeye katılım düzeyi erkek katılımc1larda daha yüksektir. Erkek katılımcılar çevre ile ilgili kurumsal sosyal sorumluluk projelerine yönelik şüphesi kadın katılımcılara oranla daha yüksek olduğu görülmektedir.

"İ̧sletmeler çevre ile ilgili kurumsal sosyal sorumluluk projesi yaptığında çevreyi kirlettiği ve bu açığı kapadığını düşünürüm” ifadesine katılım cinsiyete göre farklılık göstermektedir $(\mathrm{p}<0,05)$. Erkek katılımcıların bu ifadeye katılım düzeyleri daha yüksektir. Erkek katılımcılar işletmelerin çevre ile ilgili kurumsal sosyal sorumluluk projesi yapmasını, o işletmenin çevreyi kirlettiği ve bu açığını kapattığı düşüncesi kadınlara oranla daha yüksektir.

"Bir kurumsal sosyal sorumluluk projesine destek sağlamak satış veya satın alma şartına bağlandığında o proje inandırıcı gelmez" ifadesine katılım cinsiyete göre farklılık göstermektedir $(\mathrm{p}<0,05)$. Erkek katılımcılar bir satış ve satin alma şartına bağlanan kurumsal sosyal sorumluluk projelerini kadın katılımcılara oranla daha az inandirıcı bulmaktadir.

"Bir davranış oluşturma ya da bir davranış geliştirmek için yapılan kurumsal sosyal sorumluluk projeleri inandırıcı değildir" ifadesine katılım cinsiyete göre farklılık göstermektedir $(\mathrm{p}<0,05)$. Bu ifadeye katılım düzeyi erkek katılımcılarda kadın katılımcılara oranla daha yüksek olduğu görülmektedir. 
Tablo 7: İfadelere Katılım Düzeyinde Okudukları Programlara Gore İnandırıcılık Dağılım Durumu

\begin{tabular}{l}
\hline Okuduğunuz Program? \\
\hline \\
Eğitim alanında yapılan Kurumsal sosyal
\end{tabular}
sorumluluk projelerini inandırıcı bulurum sorumluluk projesi yaptığında bunu inandirici bulurum

\begin{tabular}{|c|c|c|c|c|}
\hline & $\mathrm{n}$ & Sira Ort & $\mathrm{X} 2$ & $\mathrm{p}$ \\
\hline Büro yönetimi ve yönetici asistanlığ1 & 30 & 111,33 & & \\
\hline Hakla ilişkiler ve Tanıtım & 62 & 133,66 & & \\
\hline İş Sağlığı ve Güvenliği & 53 & 105,96 & 12,092 &, $017 *$ \\
\hline Lojistik & 34 & 89,88 & & \\
\hline Sivil Savunma ve İtfaiyecilik & 47 & 113,87 & & \\
\hline Büro yönetimi ve yönetici asistanlığı & 30 & 100,98 & & \\
\hline Hakla ilişkiler ve Tanıtım & 62 & 129,52 & & \\
\hline İş Sağlığ́1 ve Güvenliği & 53 & 113,36 & 6,818 & 146 \\
\hline Lojistik & 34 & 101,78 & & \\
\hline Sivil Savunma ve İtfaiyecilik & 47 & 109,00 & & \\
\hline
\end{tabular}

Büro yönetimi ve yönetici asistanlığı

3098,53

Hakla ilişkiler ve Tanıtım

6298,35

Kurumların çevre ile ilgili Kurumsal sosyal sorumluluk projesi yapması beni şüpheye düşürür

İş Sağlığ1 ve Güvenliği

$53 \quad 125,77 \quad 8,757 \quad, 067$

Lojistik

34122,06

Sivil Savunma ve İtfaiyecilik

$47 \quad 123,01$
İşletmeler çevre ile ilgili KSS projesi yaptığında çevreyi kirlettiği ve bu açığı kapadığını düşünürüm
Büro yönetimi ve yönetici asistanlığı

Hakla ilişkiler ve Tanıtım

İş Sağlı̆̆1 ve Güvenliği

Lojistik

Sivil Savunma ve İtfaiyecilik

Büro yönetimi ve yönetici asistanlığı

Hakla ilişkiler ve Tanıtım

Bir kurumsal sosyal sorumluluk projesi pazarlama amacı güderse ya da koşullu satış yaparsa inandırıcı bulmam

İş Sağlığ1 ve Güvenliği

Lojistik

Sivil Savunma ve İtfaiyecilik

Bir Kurumsal sosyal sorumluluk projesine destek sağlamak satış veya satın alma
Büro yönetimi ve yönetici asistanlığı

$\begin{array}{lllll} & 30 & 123,80 & & 3,853\end{array}, 426$

$30 \quad 123,80$

62106,97

\section{1,62}

$62 \quad 115,94$

$53 \quad 120,42 \quad 4,678 \quad, 322$

$34 \quad 125,44$

$47 \quad 101,43$

30116,65

62109,97

$53 \quad 114,29 \quad 1,162 \quad, 884$

34107,01

47119,95 
şartına bağlandığında o proje inandırıcı gelmez
İş Sağllğ 1 ve Güvenliği

Lojistik

Sivil Savunma ve İtfaiyecilik

Büro yönetimi ve yönetici asistanlığı

Hakla ilişkiler ve Tanıtım

İş Sağllğ 1 ve Güvenliği

geliştirmek için yapılan Kurumsal sosyal sorumluluk projeleri inandırıcı değildir
Lojistik

Sivil Savunma ve İtfaiyecilik
53111,95

$34 \quad 103,59$

47124,46

$30 \quad 135,67$

6290,24

$53117,5513,233,010 *$

34117,03

$47 \quad 122,91$

\begin{tabular}{|c|c|c|c|c|c|}
\hline \multirow{5}{*}{$\begin{array}{l}\text { Bir kurumsal sosyal sorumluluk projesinin } \\
\text { tüm işletme tarafindan kabul görüp } \\
\text { görmediği, çalışan ve paydaşlarla birlikte } \\
\text { yürütülmesi inandırıcılığ } 1 \text { arttırır }\end{array}$} & Büro yönetimi ve yönetici asistanlığ & 30 & 103,33 & \multirow{5}{*}{6,504} & \multirow{5}{*}{, 165} \\
\hline & Hakla ilişkiler ve Tanıtım & 62 & 121,47 & & \\
\hline & İş Sağlığ 1 ve Güvenliği & 53 & 112,41 & & \\
\hline & Lojistik & 34 & 94,78 & & \\
\hline & Sivil Savunma ve İtfaiyecilik & 47 & 124,26 & & \\
\hline \multirow{5}{*}{$\begin{array}{l}\text { Kurumların kendileri menfaatleri } \\
\text { doğrultusunda Kurumsal sosyal } \\
\text { sorumluluk projesi yaptığını düşünürüm }\end{array}$} & Büro yönetimi ve yönetici asistanlığ1 & 30 & 114,87 & \multirow{5}{*}{3,978} & \multirow{5}{*}{,409 } \\
\hline & Hakla ilişkiler ve Tanıtım & 62 & 104,02 & & \\
\hline & İş Sağlığı ve Güvenliği & 53 & 126,75 & & \\
\hline & Lojistik & 34 & 113,96 & & \\
\hline & Sivil Savunma ve İtfaiyecilik & 47 & 109,87 & & \\
\hline
\end{tabular}

Araştırmanın 4. sorusu, "MYO öğrencilerinin KSS projelerinin inandırıcılığına yönelik yaklaşımılarında okudukları programlar anlamlı fark yaratır mı?” sorusuna yönelik oranlar:

"Eğitim alanında yapılan kurumsal sosyal sorumluluk projelerini inandırıcı bulurum" ifadesine katılım okunulan programa göre farklılık göstermektedir $(\mathrm{p}<0,05)$. Elde edilen sonuçlara göre katılımcılardan Hakla İlişkiler ve Tanıtım okuyanlarda bu ifadeye katılım en yüksek 133,66 iken (n: 62), Lojistik okuyanlarda 89,88 (n: 34) en düşüktür. Elde edilen sonuçlara göre Halkla Ilişkiler Ve Tanıtım programında okuyan öğrencilerin eğitim alanında yapılan kurumsal sosyal sorumluluk projelerini diğer program öğrencilerine göre daha inandırıcı bulduğu görülmektedir.

"Bir davranış oluşturma yada bir davranış geliştirmek için yapılan kurumsal sosyal sorumluluk projeleri inandırıcı değildir” ifadesine katılım okunulan programa göre farklılık göstermektedir $(p<0,05)$. Bu ifadeye katılım Büro Yönetimi ve Yönetici Asistanlığı okuyan katılımcılarda bu ifadeye katılım en yüksek 135,67 iken (n: 30), Hakla İlişkiler ve Tanıtım programında okuyan katılımcılarda bu oran 90,24 (n: 62) en düşüktür. Katılımcılar arasında Halkla Ilişkiler Ve Tanıtım programında okuyan katılımcıların bir davranış oluşturma yada bir davranış geliştirmek için yapılan kurumsal sosyal sorumluluk projelerini diğer programlarda okuyan katılımcılara oranla daha inandırıcı bulduğunu söylemek mümkündür.

Tablo 8: Öğrencilerin Bir Kurumsal Sosyal Sorumluluk Projesini Katkı Sağlamak İsteme Düzeyleri

\begin{tabular}{cccc}
\hline Kesinlikle \\
Katılmiyorum
\end{tabular} Katılmıorum Kararsızım Katılıyorum $\begin{gathered}\text { Kesinlikle } \\
\text { Katılıorum }\end{gathered}$ Ortalama




\begin{tabular}{|c|c|c|c|c|c|c|c|c|c|c|c|}
\hline & $\mathrm{n}$ & $\%$ & $\mathrm{n}$ & $\%$ & $\mathrm{n}$ & $\%$ & $\mathrm{n}$ & $\%$ & $\mathrm{n}$ & $\%$ & \\
\hline $\begin{array}{l}\text { Bir Kurumsal sosyal } \\
\text { sorumluluk projesinin } \\
\text { içerisinde bulunmak isterim }\end{array}$ & 6 & 2,7 & 11 & 4,9 & 53 & 23,5 & 45 & 19,9 & 111 & 49,1 & 4,08 \\
\hline
\end{tabular}

Araştırmanın 5. sorusu, "MYO öğrencileri KSS projelerinde görev almak ister mi?" sorusuna yönelik oranlar aşağıdaki gibidir:

Ankete katılan öğrencilerden bir KSS projesinde görev almak isteyenlerin oranı \% 69 (n156) oranındadır. Oldukça yüksek bir oranla öğrenciler kurumsal sosyal sorumluluk projelerinde yer almak istemektedirler.

Tablo 9. Okudukları Programlara Göre Öğrencilerin Bir Kurumsal Sosyal Sorumluluk Projesini Katkı Sağlamak İsteme Düzeyleri

\begin{tabular}{llllll}
\hline Okuduğunuz Program? & & n & Sira Ort & X2 & $\mathrm{p}$ \\
\hline & Büro yönetimi ve yönetici asistanlığı & 30 & 114,78 & \\
& Hakla ilişkiler ve Tanıtım & 62 & 137,18 & \\
& İş Sağlığı ve Güvenliği & 53 & 107,70 & 15,106 &, $004 *$ \\
Bir Kurumsal sosyal sorumluluk & 34 & 103,29 & \\
projesinin içerisinde bulunmak isterim & Lojistik & 47 & 95,37 & \\
& Sivil Savunma ve İtfaiyecilik & &
\end{tabular}

"Bir kurumsal sosyal sorumluluk projesinin içerisinde bulunmak isterim" ifadesine katılım okunulan programa göre farklılık göstermektedir $(\mathrm{p}<0,05)$. Elde edilen bulgulara göre, Hakla İlişkiler ve Tanıtım okuyan katılımcıların bu ifadeye katılım 137,18 (n: 62) en yüksek iken Sivil Savunma ve İtfaiyecilik okuyan katılımcılarda bu oran 97,37 (n: 47) en düşüktür.

Tablo 10. Öğrencilerin Cinsiyetine Göre Bir Kurumsal Sosyal Sorumluluk Projesini Katkı Sağlamak İsteme Düzeyleri

\begin{tabular}{lrrrr}
\hline Cinsiyet & n $\begin{array}{c}\text { Sira } \\
\text { Ort }\end{array}$ & U & $\mathrm{p}$ \\
\hline Bir Kurumsal sosyal sorumluluk projesinin içerisinde bulunmak isterim & Erkek 104 & 101,19 & $5064,000 \quad, 005^{*}$ \\
\hline
\end{tabular}

"Bir kurumsal sosyal sorumluluk projesinin içerisinde bulunmak isterim" ifadesine katılım cinsiyete göre farklılık göstermektedir $(\mathrm{p}<0,05)$. Elde edilen sonuçlara göre kadın katılımcıların kurumsal sosyal sorumluluk projelerinin içerisinde bulunma isteği erkek katılımcılara oranla daha yüksektir. Cinsiyete göre katılım düzeylerinde anlamlı bir fark bulunmaktadır.

\section{SONUÇ}

Halkla ilişkilerin en önemli amaçlarından biri, örgütün özel çıkarları ile hedef kitlenin ve toplumun çıkarları arasında denge sağlayabilmektir (Grunig,2005: 259). Kurumsal sosyal sorumluluk kavramını, halkla ilişkiler perspektifinden değerlendirdiğimizde hedef kitlenin çıkarları düşünerek gerçekleştirilen, inandırıcılığ yüksek ve sosyal sorumluluk bilinci ile tasarlanan KSS projeleri hedef kitle ile arada bir bağ kurabilmektedir. Halkla ilişkilerin uygulama biçimlerinden biri olan sosyal sorumluluk, hedef kitlesi ile işletme arasında bir köprü vazifesi görebilmelidir. 
Toplum tarafından yetersiz görülen alanlarda KSS projeleri gerçekleştirmek ve toplumun sorunlarına yönelerek hareket etmek gerekmektedir. Araştırma sonuçlarına göre öğrenciler öncelikli olarak toplumun sorunlarına yönelik eksikliklerin giderilmesi gerektiğini verdikleri yanıtlar ile dile getirmektedir. Özellikle eğitim, sağlık, çevre gibi temel sorunların çözümü için projelere öncelik istemektedirler. Daha sonraki aşamada kültür-sanat faaliyetleri yer almaktadır. Bu nedenle ülkelerin sorunlarına duyarlılık gösteren projeler gerçekleştirmek önemli hale gelmektedir.

İşletmeler KSS projeleri tercihlerinde toplumun önceliklerini göz önünde bulundurması ve bu doğrultuda projeler üretmesi ya da projelere destek olması hedef kitle açısından olumlu karşılandığını söylemek mümkündür. Bir diğer önemli nokta ise, gerçekleştirilen projelerde çalışanların desteğinin alınmasıdır. Tüm çalışanların katılımıyla yapılan projelerin daha inandırıcı olduğu sonucu ortaya çıkmaktadır. MYO öğrencilerinin büyük çoğunluğu bir kurumsal sosyal sorumluluk projesinde görev almak istemektedir. Özellikle Halkla İlişkiler ve Tanıtım programı öğrencileri büyük oranda KSS projelerine dahil olmak istemektedirler.

Araştırmaya katılan öğrenciler, çevre ile ilgili kurumsal sosyal sorumluluk projesi yapıldığında şüpheye düşmemediklerini ifade etmeketedirler. Ancak, katılımcılar kurumların yaptıkları kurumsal sosyal sorumluluk projeleri ile çevre kirliliğine sebebiyet verdikleri için bu alanda projeler tasarladıkları inancındadırlar. Ayrıca bir kurumsal sosyal sorumluluk projesi şirketin tüm çalışanları tarafından desteklendiğinde tüm işletme tarafindan kabul gördüğü algısı oluşmaktadır. Tüm işletme tarafından kabul gören projelerin inandırıcılığının daha yüksek olduğu sonucu ortaya çıkmaktadır. Hayata geçirilen projelerin şirketle organik bağı olan tüm paydaşlarla birlikte yürütülmesi olumlu bir imaj oluşturmaktadır. Bu nedenle işletmelerin bir proje planı yaparken tüm kurumun onaylayabileceği ve katk1 sağlayabileceği alanlara yönelmeleri hatta kendi faaliyet alanlarına uygun projeler yaparak çalışanları da projeye dahil etmeleri başarı için önemli olmaktadır.

Bir kurumsal sosyal sorumluluk projesinden daha spesifik sonuçlar elde etmek için markalar ve gerçekleştirilen kurumsal sosyal sorumluluk projeleri örnekleri üzerinden anket soruları oluşturmak ve tek tek proje değerlendirmesi yapılabilecek bir grup odak görüşmesi gerçekleştirmek mümkündür. Bu açıdan bir ya da daha fazla KSS projesini ele alarak proje bazlı inandırıcılık ve etki analizi yapılabilir.

Bir sosyal sorumluluk projesi satış koşulu taşıyorsa bu proje olumsuz karşılanmakta ve şirketlerin satış niyeti taşıdığı algısı oluşmaktadır. Bu niyette olan şirketlerin temelinde sosyal sorumluluk bilinci ile hareket etmedikleri algısı da oluşmaktadır. Markalar gerçekleştirilen projeler ile halkla ilişkiler hedeflerine ulaşma imkânı bulmaktadır. En önemli halkla ilişkiler hedefi olarak görülen imaj, yapılan projelerin hedef kitle tarafindan inandırıcı olarak algılanması sonucunda olumlu olmaktadır. 


\section{KAYNAKÇA}

Carroll, Archie B. ve Kareem M. Shabana, (2010) “The Business Case for Corporate SocialResponsibility: A Review of Concepts,Research and Practice", International Journal of Management Reviews, Vol.12 No.1, DOI: 10.1111/j.1468-2370.2009.00275, pp. 85-105

Carroll, Archie B., (1979) "A Three-Dimensional Conceptual Model of Corporate Performance", The Academy of Management Review, Vol. 4, No. 4, pp. 497-505

Carroll, Archie B., (1991) "The Pyramid of Corporate Social Responsibility: Toward The Moral Management of Organizational Stakeholders”, Business Horizons, Vol.34, No.4, pp.39-48

Carroll, Archie B., (1999) "Corporate Social Responsibility Evolution of a Definitional Construct”, BUSINESS \& SOCIETY, Vol. 38 No. 3, pp.268-295

Coşkun, Gül, (2010) Kurumsal Pazarlama ve Sosyal Sorumluluk, Nobel Yayınları, İstanbul.

Göztaş Aylin ve E. Pelin Baytekin, (2009) "Sosyal Sorumluluk Kampanyalari ile Çocukların Bilinçlendirilmesi ve Eğitimi Türkiye’den Bir Uygulama Örneği: Aygaz ‘Dikkatli Çocuk’ Kazalara Karşı Bilinçlendirme Kampanyası”, Journal of Yasar University, 4(13), s.1997-2015

Grunig, James.E., Halkla İlişkiler ve İletişim Yönetiminde Mükemmellik, çev. Elif Özsayar, (2005) Rota Yayınları, İstanbul

Kotler Philip, ve Nancy R Lee, (2006) Kurumsal Sosyal Sorumluluk, MediaCat, İstanbul.

Kotler, Philip ve diğ, (2012), İyi Şirket, Optimist, İstanbul.

Miraç Zeynep, (2015), Okuyan Kızlar Aydınlık Yarınlar, Elma Basım, İstanbul.

Okay Ayla ve Aydemir Okay, (2010) Hakla İlişkiler Kavram, Strateji ve Uygulamaları, DER Yayınları, İstanbul.

Özdemir, Hilal, (2009) “Kurumsal Sosyal Sorumluluğun Marka İmajına Etkisi”, İstanbul Ticaret Üniversitesi Sosyal Bilimler Dergisi, Y11:8 Sayı:15 Bahar, s.55-72.

Peltekoğlu Balta, Filiz ve Emel Tozlu, (2017) Halkla İlişkiler ve Gönüllülük Ekseninde Türkiye'de Kurumsal Sosyal Sorumluluk Projeleri ve Bin Yıl Kalkınma Hedefleri, Selçuk İletişim, 10 (1), s.5-31

Peltekoğlu Balta, Filiz, (2012) Halkla İlişkiler Nedir?, 7. bs., Beta Yayınları, İstanbul.

Peltekoğlu Balta, Filiz, (2018) Halkla İlişkiler Nedir?, 10. bs., Beta yayınları, İstanbul.

Sosyal Sorumluluk Platformu, http://www.sosyalsorumluluk.org/ayisigi/, 11/04/2016 